Acta Genet Med Gemellol 33:435-450 (1984)

(C) 1984 by The Mendel Institute, Rome

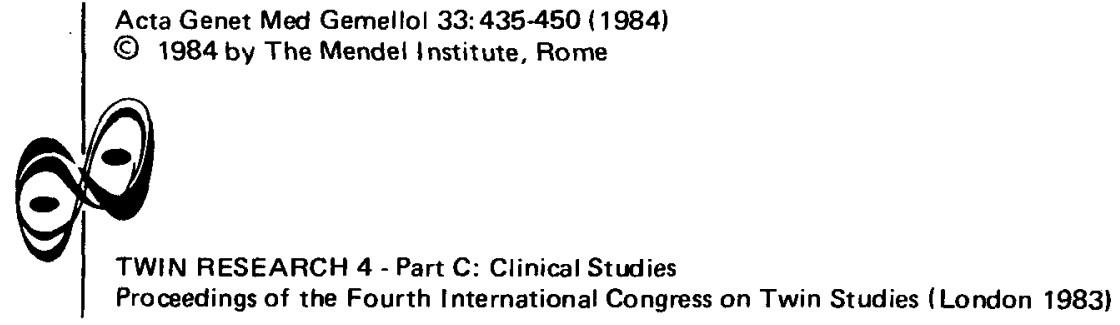

\title{
Causes of Variation in Drinking Habits in a Large Twin Sample
}

\author{
R. Jardine ${ }^{1}$, N.G. Martin ${ }^{1,2}$ \\ ${ }^{1}$ Department of Population Biology, Research School of Biological Sciences, Australian \\ National University, Canberra; and ${ }^{2}$ Department of Human Genetics, Medical College of \\ Virginia, Richmond
}

\begin{abstract}
A genetic analysis of alcohol consumption in 3810 pairs of adult twins is reported. When no correction was made for age, individual environmental variance, including non-repeatable errors of reporting, accounted for approximately $44 \%$ of variation in both sexes. In females, there was no evidence of shared environmental effects and $56 \%$ of the variance was genetic in origin. In males, only $36 \%$ of the variance was genetic and common environmental effects accounted for the remaining $20 \%$ of individual differences.

For females, the results for younger (30 years and under) and older (over 30) twins were similar. For males, however, the effect of age was striking. In younger male twins over $60 \%$ of the variance was genetic in origin, with the remaining variance due to environmental influences unique to the indiviudal. In older twins genetic differences do not appear to be important, with approximately $50 \%$ of the total variance due to individual environmental differences and the remaining $50 \%$ due to the effect of the common family environment. Our results suggest that both age and sex need to be considered when analysing the causes of variation in alcohol consumption.
\end{abstract}

Key words: Alcohol consumption, Twins, Common environment, Age, Sex, Genetic factors

\section{INTRODUCTION}

The existence of large variations between people in the use of alcohol has long been established and although a number of studies have investigated the contribution of genetic and environmental factors to variation in alcohol use, the results show little agreement. 
Perry [21] in America, in a study of 84 pairs of twins, found a substantial heritability of 0.56 for the amount of alcohol consumed per week. In contrast, Conterio and Chiarelli [7], studying drinking behaviour in a sample of 77 Italian male twins, found that $\mathrm{MZ}$ twins were not significantly more alike than DZ twins with respect to a drinking/nondrinking dichotomy or a wine drinking/wine non-drinking dichotomy. Also, there was no difference between $\mathrm{MZ}$ and $\mathrm{DZ}$ concordance for quantity of wine consumed. While both these studies were based on small samples, larger st udies have also failed to give conclusive results.

Partanen et al [19] studied drinking behaviour in 902 pairs of Finnish male twins aged between 28 and 37 years and derived three measures of alcohol consumption based on a factor analysis of drinking items. The first, Density, measured the frequency of alcohol consumption. The second, Amount, measured both the quantity of alcohol consumed and the duration of drinking during the last reported drinking occasion. The third, Lack of Control, measured the individual's control over his consumption. The results showed that genetic factors were an important determinant of a person's drinking behaviour, the heritability estimates for Density and Amount being 0.39 and 0.36 respectively. Lack of Control had a lower heritability of 0.14 . An interesting difference was found in the comparison of younger (28-33) and older (34-37) pairs. The heritabilities were much higher for younger than older twins for both Density (0.52 vs 0.31 ) and Lack of Control $(0.54$ vs -0.07$)$. The heritability for amount was 0.37 for both age groups.

Kaprio et al [14], in a study of 5044 Finnish male twins aged 18 and over found a heritability of 0.51 for alcohol use. However, when they analysed the data separately for 10 year age cohorts, the heritability was close to zero for those older than 60 . These results and those of Partanen et al [19] suggest that age is an important factor which needs to be considered in genetic studies of drinking behaviour.

Different results for the causes of variation in drinking behaviour are also obtained when one considers males and females separately. Cederlöf et al [3] in Sweden studied alcohol consumption in 13000 pairs of twins and found higher concordance rates in $\mathrm{MZ}$ and DZ twins for drinking and particularly for excessive drinking, but that this higher concordance was much more pronounced in females than males. Clifford et al [6], in a study of 399 English twin pairs, found that genetic influences seemed to be important in alcohol consumption in both males and females. However, in females there was also evidence of a competition effect, the consumption of one twin, whether high or low, apparently influencing the other twin to drink in the opposite manner.

Overall, the results of these various studies suggest that there are genetic factors contributing to variation in alcohol consumption but that their importance depends on the age and sex of the individual.

We report here some preliminary results from one of the largest twin studies of alcohol consumption. Our results support the conclusion that genetic factors are important to variation in consumption but that there are differences in the relative contribution of genetic and environmental influences depending on age and sex.

\section{METHOD}

\section{Sample}

The sample comprised 3810 pairs of twins from the Australian National Health and Medical Research 
Council Twin Registry. The sex, zygosity and age distribution of the sample is shown in Table 1 . The twins were participants in a postal questionnaire study of drinking and smoking behaviour, sleep patterns, general health, personality and attitudes. Pilot prestudy responses, which can be used to test the repeatability of the measures, are also available for 96 individuals. Only items relating to alcohol consumption will be analysed here. The sample and method of zygosity diagnosis have been described in detail elsewhere [12].

Table 1 - Age, Sex and Zygosity Composition of the Sample

\begin{tabular}{lccccc}
\hline & $\begin{array}{c}\mathrm{MZ} \\
\text { females }\end{array}$ & $\begin{array}{c}\mathrm{MZ} \\
\text { males }\end{array}$ & $\begin{array}{c}\mathrm{DZ} \\
\text { fermales }\end{array}$ & $\begin{array}{c}\mathrm{DZ} \\
\text { males }\end{array}$ & $\begin{array}{c}\mathrm{DZ} \\
\text { opposite-sex }\end{array}$ \\
\hline Number of pairs & 1233 & 567 & 751 & 352 & 907 \\
Mean age (years) & 35.66 & 34.36 & 35.35 & 32.26 & 32.90 \\
Standard deviation & 14.27 & 14.02 & 14.27 & 13.88 & 13.85 \\
Age range & $18-88$ & $18-79$ & $18-84$ & $18-83$ & $18-79$ \\
\hline
\end{tabular}

\section{Measures}

The items relating to alcohol use from the entire twin questionnaire are given in the Appendix. We have looked at two measures of alcohol consumption based on these items:

1. Normal weekly alcohol consumption - based on items 35-39 we have calculated an average of weekly alcohol consumption which reflects usual drinking behaviour.

2. Alcohol consumption last week - based on item 40 we have calculated the actual amount of alcohol consumed over the course of the previous week. Both these measures were calculated as the total number of standard drinks (beer, wine, spirits, etc) consumed. A comparison of these two measures allows us to assess the variability of consumption and/or response.

\section{RESULTS}

\section{Scaling}

In a genetic analysis it is most appropriate to chose a scale of measurement where there is no genotype-environment interaction so that genetic and environmental effects are additive. Jinks and Fulker [13] showed that certain types of genotype-environment interaction could be detected by regressing the absolute differences of $M Z$ pairs (a measure of individual environmental differences $-E_{1}$ ) on their pair sums (a measure of genotype $(G)$ and/or family environment $\left(E_{2}\right)$ ). Martin and Eysenck [17] showed that such interactions could be detected with great sensitivity but they could nearly always be removed by a transformation of the scale of measurement which lessened departures from normality.

Both raw measures of alcohol consumption show significant and substantial linear regressions and these are considerably reduced by logarithmic transformation (Table 2). Although this results in an increase in the quadratic components, other transformations $\left[\log _{10}(x+3)\right.$ or $\left.\log _{10}\left(\log _{10}(x+1)\right)\right]$ gave no greater improvement so we regard this transformation as most appropriate. The significance of the $\mathrm{DZ}$ regressions will be discussed later. In most cases, transformations have a negligible effect on the results of fitting models to variance components, but when there are extreme deviations from normality, as for the measures of alcohol consumption, the results may differ markedly [17]. Consequently, our genetical analysis will be based on the log transformed measures of alcohol consumption. 


\section{Sampling}

An assumption fundamental to the twin method is that $M Z$ and $D Z$ twins have been drawn at random from the same population and we can test this by comparing the subgroup means and variances. Although for the raw scores, the variances of both consumption measures are significantly greater in $M Z$ than $D Z$ females, and the variance of normal weekly consumption is significantly greater in $M Z$ than $D Z$ males, these differences all become non-significant after transformation. The means of both consumption measures are, however, significantly greater in males than females (Table 3), which confirms previous results from surveys of alcohol consumption in Australian samples [1, 23]. Males also have a greater variance in consumption than females. These results are identical for both the raw and transformed scores. In both males and females the two measures of consumption correlate highly for both the raw scores $(0.70$ in females, 0.82 in males), and the transformed scores $(0.83,0.86)$, but normal weekly consumption tends to provide a lower estimate of alcohol consumption than consumption last week.

Since the purpose of a genetical analysis of twin data is to make inferences about the causes of variation in the population, it is also important that twins are comparable with non-twin subjects. As a result of the Australian Bureau of Statistics survey of drinking and smoking habits carried out in 1977 [1], information about the alcohol consumption patterns of Australian adults aged 18 years and over is available, although it is known that such survey estimates of consumption significantly underreport estimates of alcohol consumption based on sales statistics $[11,20,22]$. $\Lambda$ comparison of the stated daily alcohol consumption of the twin respondents (calculated from consumption last week) with expected consumption based on ABS [1] data showed that our male twins had similar drinking patterts to the general population (Table 4). However, our female twins showed a greater froportion of drinkers than the national average (Table 4), although this difference may reflect a change in drinking hathits over the three years since the ABS [1] data were collected.

\section{Repeatability}

Prior to mailing the questionnaire to the entire adult sample, a pilot questionnaire had been mailed to 100 pairs of adult twins in order to assess likely response rate and any problems in construction of the questionnaire. Only minor changes were made to the final questionnaire as a result of problems observed in the pilot one and when it was mailed some months later, 96 responses from the original pilot sample of 200 were obtained. We have used these duplicate responses to assess the short-term repeatability of the alcohol consumption measures.

Analysis of the alcohol consumption of the 96 individuals who completed both the pilot and main questionnaire (Table 5) shows that, although they were typical of the iotal sample in distribution of age, they were somewhat atypical in their consumption patterns. For both the raw and transformed scores, both males and females have higher normai weekly consumption and lower consumption last week than the total sample. Also, for both sexes, the variance of the two alcohol measures is greater in the pilot sample than the total sample, and this is more pronounced for the measures of normal weekly consumption.

Separate analyses of variance of the alcohol consumption measures to obtain mean squares between $\left(\mathrm{MS}_{\mathrm{b}}\right)$ and within $\left(\mathrm{MS}_{\mathrm{w}}\right)$ enabled calculation of repeatabilit ies (intraclass correlations) as $\mathrm{R}_{\mathrm{i}}=\left(\mathrm{MS}_{\mathrm{b}}-\mathrm{MS}_{\mathrm{w}}\right) /\left(\mathrm{MS}_{\mathrm{b}}+\mathrm{MS}_{\mathrm{w}}\right)$. In both males and females, consump- 

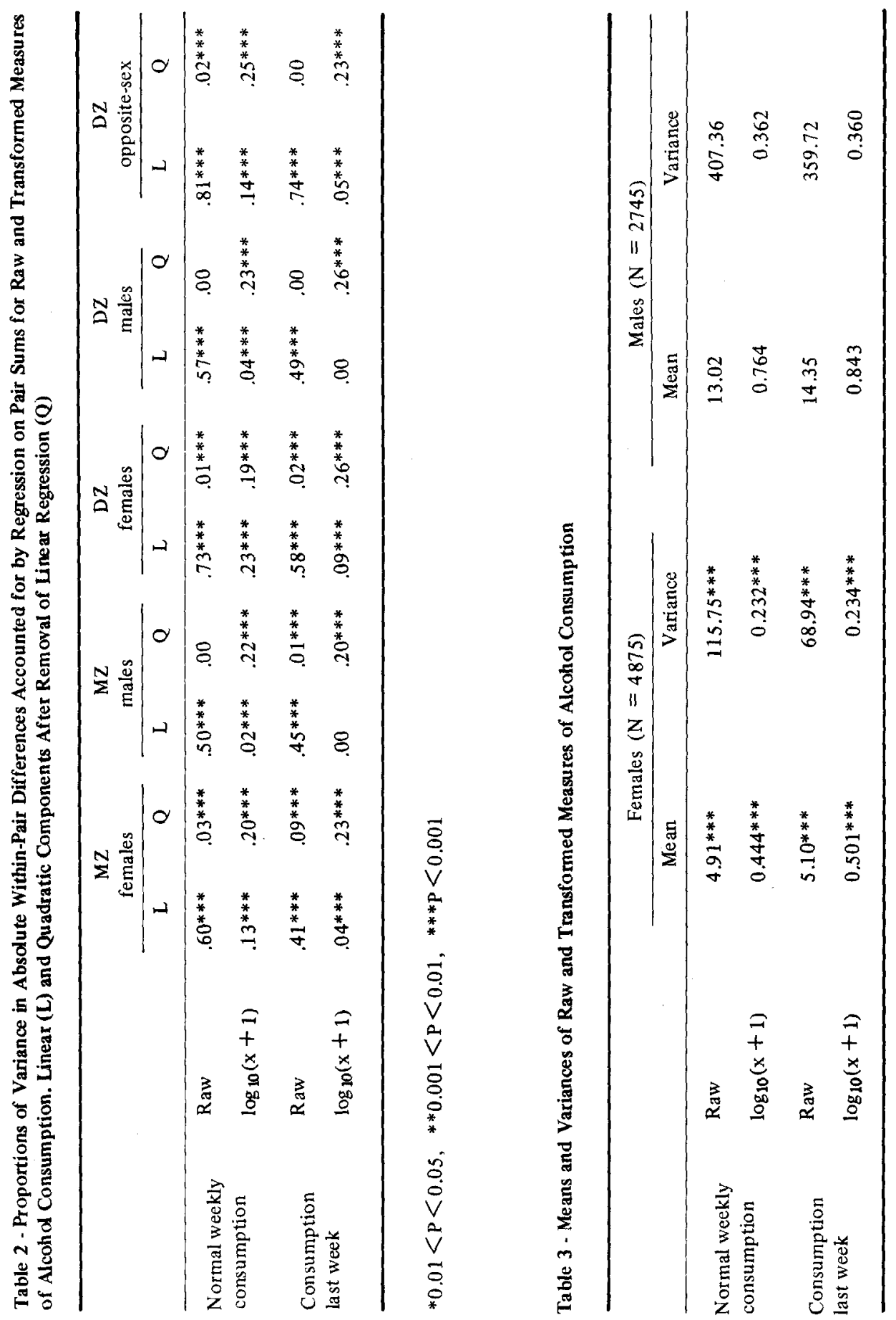

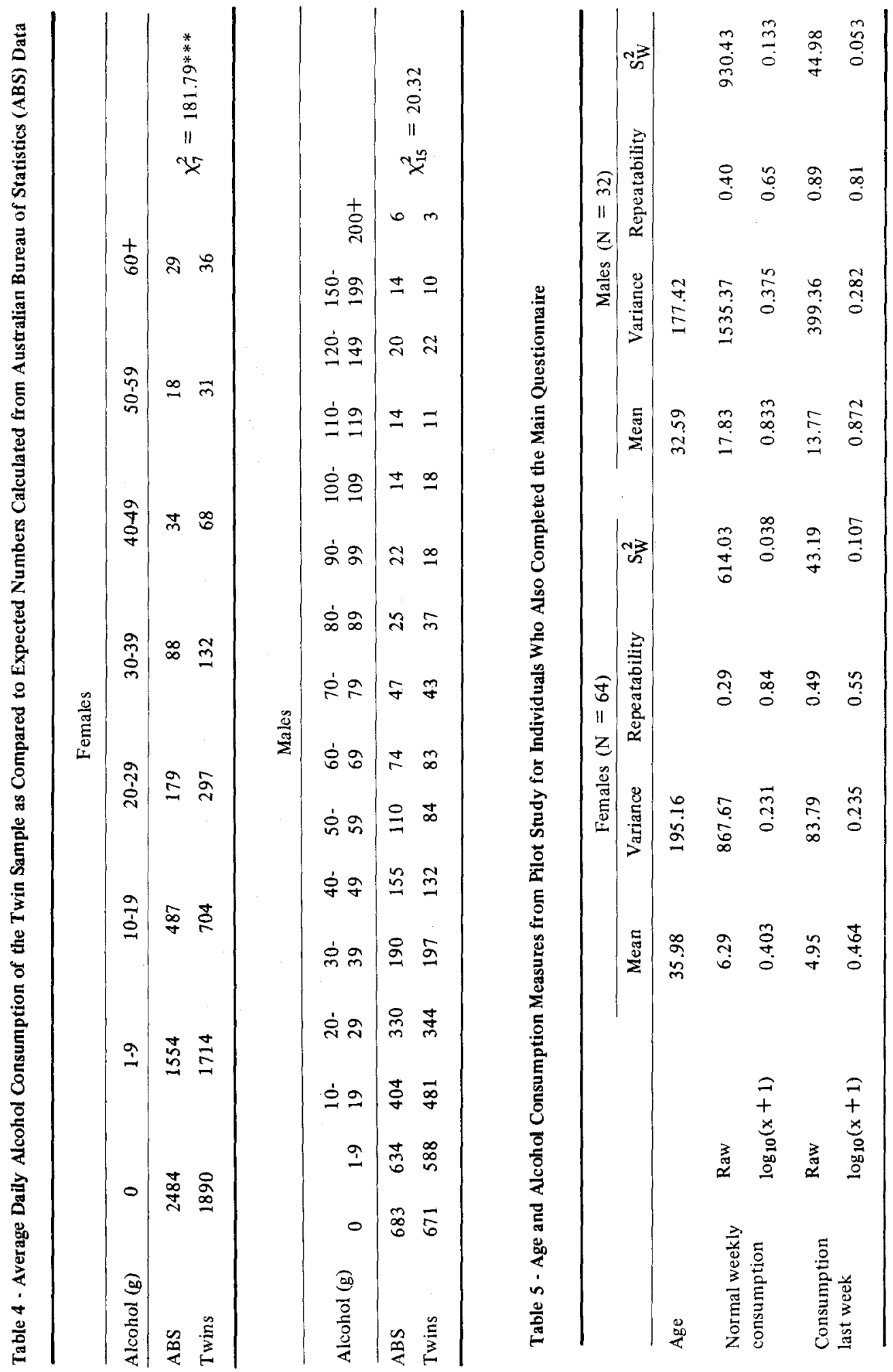


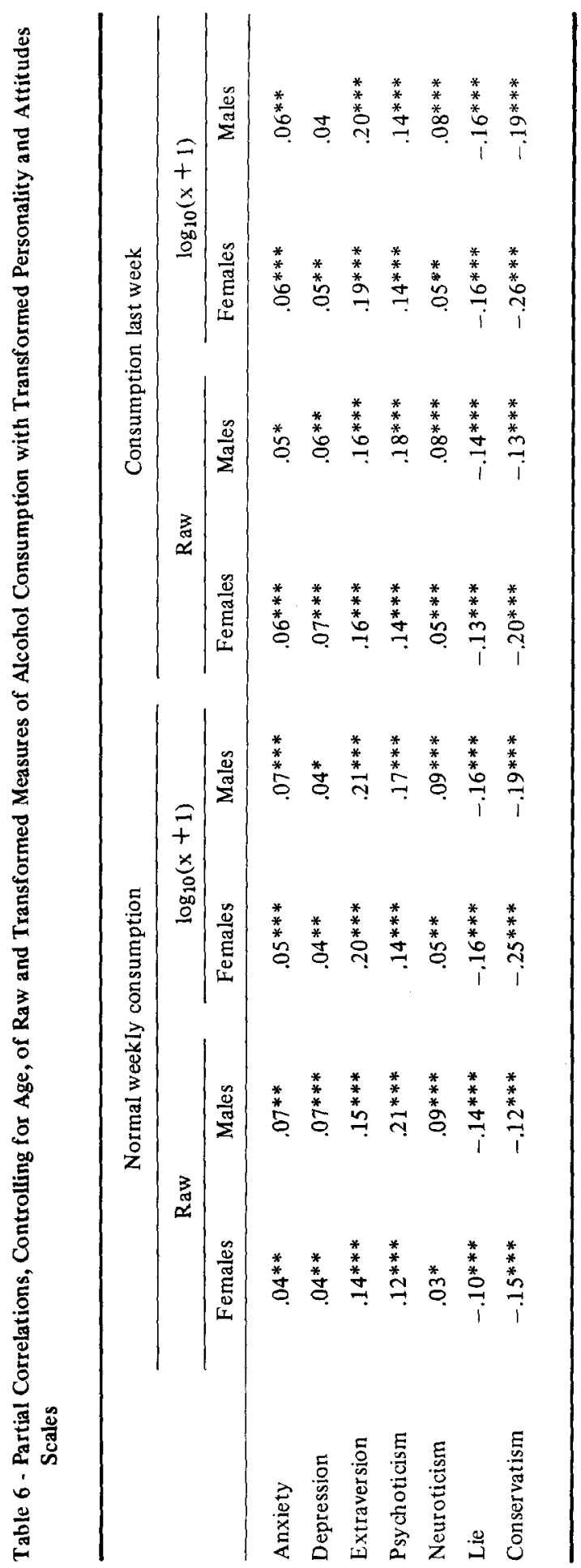


tion last week is more reliable than normal weekly consumption, and there is a tendency for the $\log$ transformation to improve reliability. The reliabilities also tend to be higher in males than females. The within-individual variance components $\left(\mathrm{S}_{\mathrm{W}}^{2}=\mathrm{MS}_{\mathrm{W}}\right)$ are also shown in Table 5 and these are estimates of the portion of the total variance which is unrepeatable and will include measurement error. For both measures of consumption, $\mathrm{S}_{\mathrm{W}}^{2}$ is higher in males than females.

\section{Correlations with Personality Variables}

Twins also completed the Eysenck Personality Questionnaire [10], the Delusions-Symptoms-States Inventory [2] and the Conservatism Scale (C-Scale) developed by Wilson and Patterson [25]. To improve the properties of the scales, extraversion, psychoticism, neuroticism and lie scores were all transformed to angles, and anxiety and depression were subjected to logarithmic transformation. Conservatism scores were untransformed. The partial correlations, controlling for age, between the measures of alcohol consumption and the transformed personality and attitude scales are shown in Table 6 . Individuals with higher levels of consumption tend to be more anxious, depressed, extraverted, psychotic and neurotic, and score lower on the lie and conservatism scales. These results are similar to previous studies which have demonstrated a relationship between alcohol consumption and extraversion $[15,19]$, anxie ty $[19,24]$ and neuroticism $[15,19]$.

\section{Genetical Analysis}

Alternative models of trait variation are fitted to between- and within-pairs mean squares by iterative weighted least squares $[4,8,9]$. A chi-square test of goodness of fit, based on expected mean squares calculated from the least-squares parameter estimates, provides a test of the adequacy of each model.

Where there is a sex difference in means, the within-pairs mean squares (WMS) of $D Z$ opposite-sex pairs is inflated by an amount $(n / 2)(\bar{M}-\bar{F})^{2}$, where there are $n$ pairs, $\bar{M}$ is the male mean and $\bar{F}$ the female mean. Significant sex differences in means were found for both measures of consumption (Table 3 ) and we corrected for this by calculating the residual WMS (with $n-1$ df) given by $\frac{n}{n-1}$ WMS $\left.-1 / 2(\bar{M}-\bar{F})^{2}\right]$.

Where a variable is strongly age dependent, this inflates the between-pairs mean square (BMS). The linear and quadratic age correlations with the log transformed measures of normal weekly consumption $(-0.04$ and -0.05 in females, -0.05 and -0.07 in males) and consumption last week $(-0.06$ and $-0.07,-0.06$ and -0.08$)$ are significant in every case but are not substantial, so we have not corrected for this age dependence. The mean squares for the consumption measures and their degrees of freedom, both corrected for sex differences, are shown in Table 7.

Examining whether twins become more or less similar with age by correlating absolute within-pair differences with age results in small and non-significant correlations for both measures of consumption. This indicates that if environmental circumstances of co-twins become more different as they get older, these do not appear to produce any greater differences in alcohol consumption.

A simple model for the possible sources of variance contributing to mean squares from a twin study is shown in Table $8 . E_{1}$ is environmental variance within-families, specific to the individual and shared with no one else, not even members of the same family. It also includes measurement error. $E_{2}$ is environmental variation shared by co-twins but differing between twin pairs and will include cultural and parental treatment effects. $V_{A}$ is the genetic variance due to the additive effects of genes in the absence of 
Table 7 - Observed Transformed Mean Squares and Their Degrees of Freedom, Corrected for Sex Differences, for the Measures of Alcohol Consumption

\begin{tabular}{|c|c|c|c|c|c|}
\hline & & \multicolumn{2}{|c|}{ Normal weekly consumption } & \multicolumn{2}{|c|}{ Consumption last week } \\
\hline & & $\mathrm{df}$ & Mean square & $\mathrm{df}$ & Mean square \\
\hline \multirow{2}{*}{ MZ female } & Between & 1232 & .3742 & 1232 & .3710 \\
\hline & Within & 1233 & .1032 & 1233 & .1075 \\
\hline \multirow{2}{*}{ MZ male } & Between & 566 & .5722 & 566 & .5548 \\
\hline & Within & 567 & .1510 & 567 & .1607 \\
\hline \multirow{2}{*}{ DZ female } & Between & 750 & .2933 & 750 & .2905 \\
\hline & Within & 751 & .1597 & 751 & .1668 \\
\hline \multirow{2}{*}{ DZ male } & Between & 351 & .5141 & 351 & .5002 \\
\hline & Within & 352 & .1948 & 352 & .2146 \\
\hline \multirow{2}{*}{ DZ opposite-sex } & Between & 906 & .3578 & 906 & .3699 \\
\hline & Within & 906 & .2318 & 906 & .2248 \\
\hline
\end{tabular}

Table 8 - Simple Model for Twin Mean Squares

\begin{tabular}{clccc}
\hline & Mean squares & $\mathrm{E}_{1}$ & $\mathrm{E}_{2}$ & $\mathrm{~V}_{\mathrm{A}}$ \\
\hline \multirow{2}{*}{ MZ female } & Between & 1 & 2 & 2 \\
& Within & 1 & 0 & 0 \\
MZ maie & Between & 1 & 2 & 2 \\
& Within & 1 & 0 & 0 \\
DZ female & Between & 1 & 2 & $3 / 2$ \\
& Within & 1 & 0 & $1 / 2$ \\
DZ male & Between & 1 & 2 & $3 / 2$ \\
& Within & 1 & 0 & $1 / 2$ \\
DZ opposite-sex & Between & 1 & 2 & $3 / 2$ \\
& Within & 1 & 0 & $1 / 2$ \\
\hline
\end{tabular}


assortative mating. Dominance variation $\left(\mathrm{V}_{\mathrm{D}}\right)$ is not included in our models because it is entirely confounded with $\mathrm{E}_{2}$ and $\mathrm{V}_{\mathrm{A}}$ in twin data. Martin et al [16] showed that the sum-difference regression test used in $\mathrm{MZ}$ twins to detect genotype-environment interaction could be used in $\mathrm{DZ}$ twins to detect directional non-additivity (dominance or epistasis) or unequal gene frequencies. The results of this analysis (Table 2) showed that $\mathrm{DZ}$ regressions were no greater than their $\mathrm{MZ}$ counterparts. Because this test has proved powerful in detecting genetical non-additivity for other traits in much smaller samples $[4,18]$, we conclude that directional non-additivity is not an important source of variation in alcohol consumption.

A sensible hierarchy of models is to first fit $\mathrm{E}_{1}$ alone. Failure of this most simple model will indicate that there is significant between families variation to be explained. $A$ model including both $E_{1}$ and $E_{2}$ will test whether the between families variation is entirely environmental in origin, while the $E_{1} V_{A}$ model will test whether it is entirely genetic. If both two parameter models fail, then a model including all three sources of variation $\left(E_{1} E_{2} V_{A}\right)$ may be tested.

Models are first fitted to the mean squares for males and females separately and then to all eight statistics together. A chi-square to test the heterogeneity of fit of a given model over sexes can then be calculated by adding the separate chi-square values for males and females and subtracting from the corresponding chi-square for the combined male and female data. If there is no significant heterogeneity, then we may proceed to fit the model to all ten mean squares including those from the DZ opposite-sex twins. If the heterogeneity is significant, then different models must be considered for males and females. As, in fact, different models were appropriate for the two sexes, the results of fitting these models to mean squares for normal weekly consumption and consumption last week are shown for males and females separately (Table 9). In every case, a model $\left(E_{1}\right)$ postulating that all variation was due to individual environmental experiences failed badly and is omitted from the summary table.

For both measures of consumption in females, the $E_{1} V_{A}$ model is most appropriate, while in males the $E_{1} E_{2} V_{A}$ model provides a better fit. Inspection of the parameter estimates also reveals that there is a larger $E_{1}$ component for males than females but a similar estimate of $V_{A}$ in both sexes.

A model which specifies a common $V_{A}$ parameter, an $E_{2}$ component in males and different sized $E_{1}$ effects in males and females has been described and illustrated previously [9]. The various terms are derived as usual except that the effects are defined separately for males and females. The result of fitting this model to the two measures of consumption is shown in Table 10 . In both these measures about $55 \%$ of the variation in consumption between females and $36 \%$ between males is due to the additive effects of genes. In males, approximately $20 \%$ of the variation is due to environmental influences shared by brothers, but there is no evidence of family environmental factors influencing alcohol consumption in females. We may also subtract the values of $S_{w}^{2}$, obtained from the repeatability data, from the estimates of $E_{1}$ and so estimate the proportion of total variance due to non-repeatable "error" and that due to repeatable individual environmental differences (Table 11).

\section{Comparison of Older and Younger Pairs}

Since the results of previous studies $[14,19]$ had indicated that the relative contribution of genetic and environmental factors to variation in alcohol consumption might depend 
Table 9 - Summary of Model Fitting for log Transformed Normal Weekly Consumption

\begin{tabular}{|c|c|c|c|c|c|c|}
\hline & $\mathrm{E}_{1}$ & $\mathrm{E}_{2}$ & $\mathrm{~V}_{\mathrm{A}}$ & $\mathrm{df}$ & $\chi^{2}$ & $\mathrm{~h}^{2}$ \\
\hline \multicolumn{7}{|l|}{ Female } \\
\hline $\mathrm{E}_{1} \mathrm{E}_{2}$ & $.125 * * *$ & $.110^{* * *}$ & & 2 & $60.76 * * *$ & \\
\hline $\mathrm{E}_{1} \mathrm{~V}_{\mathrm{A}}$ & $.102 * * *$ & & $.131^{* * *}$ & 2 & 1.50 & $.56 \pm .02$ \\
\hline $\mathrm{E}_{1} \mathrm{E}_{2} \mathrm{~V}_{\mathrm{A}}$ & $.103 * * *$ & .010 & $.121 * * *$ & 1 & 1.09 & \\
\hline \multicolumn{7}{|l|}{ Male } \\
\hline $\mathrm{E}_{1} \mathrm{E}_{2}$ & $.168 * * *$ & $.191 * * *$ & & 2 & $8.62 *$ & \\
\hline$E_{1} V_{A}$ & $.143^{* * *}$ & & $.211 * * *$ & 2 & $11.56^{* *}$ & \\
\hline $\mathrm{E}_{1} \mathrm{E}_{2} \mathrm{~V}_{\mathrm{A}}$ & $.151^{* * *}$ & $.118^{* * *}$ & $.091^{* *}$ & 1 & .07 & $.25 \pm .09$ \\
\hline
\end{tabular}

Summary of Model Fitting for log Transformed Consumption Last week

\begin{tabular}{|c|c|c|c|c|c|c|}
\hline & $E_{1}$ & $\mathrm{E}_{2}$ & $\mathrm{~V}_{\mathrm{A}}$ & $\mathrm{df}$ & $\chi^{2}$ & $h^{2}$ \\
\hline \multicolumn{7}{|l|}{ Female } \\
\hline $\mathrm{E}_{1} \mathrm{E}_{2}$ & $.130 * * *$ & $.105^{* * *} *$ & & 2 & $61.63^{* * *}$ & \\
\hline $\mathrm{E}_{1} \mathrm{~V}_{\mathrm{A}}$ & $.107^{* * * *}$ & & $.128 * * *$ & 2 & .84 & $.55 \pm .02$ \\
\hline $\mathrm{E}_{1} \mathrm{E}_{2} \mathrm{~V}_{\mathrm{A}}$ & $.107^{* * *}$ & .002 & $.126^{* * *}$ & 1 & .82 & \\
\hline \multicolumn{7}{|l|}{ Male } \\
\hline $\mathrm{E}_{1} \mathrm{E}_{2}$ & $.181^{* * *}$ & $.176^{* * *}$ & & 2 & $10.74^{* *}$ & \\
\hline $\mathrm{E}_{1} \mathrm{~V}_{\mathrm{A}}$ & $.155^{* * *}$ & & $.201 * * *$ & 2 & $6.52 *$ & \\
\hline $\mathrm{E}_{1} \mathrm{E}_{2} \mathrm{~V}_{\mathrm{A}}$ & $.161^{* * *}$ & $.089 * *$ & $.108 * *$ & 1 & .00 & $.30 \pm .10$ \\
\hline
\end{tabular}

Table 10 - Parameter Estimates ( \pm SE) and Heritabilities $\left(h^{2}\right)$ from Fit of Models Incorporating Different Components of Variation for Males and Females

\begin{tabular}{|c|c|c|c|c|}
\hline & $\mathrm{V}_{\mathrm{A}}$ & $\mathrm{E}_{1 \mathrm{M}}$ & $\mathrm{E}_{1 \mathrm{~F}}$ & $\mathrm{E}_{\mathbf{2}} \mathrm{M}$ \\
\hline \multirow[t]{3}{*}{$\begin{array}{l}\text { Normal weekly } \\
\text { consumption }\end{array}$} & $.130 \pm .006$ & $.146 \pm .008$ & $.102 \pm .004$ & $.084 \pm .013$ \\
\hline & \multicolumn{4}{|c|}{$x_{6}^{2}=3.00$} \\
\hline & $\mathrm{h}^{2}$ Fem & $.56 \pm .02$ & $\mathrm{~h}^{2} \mathrm{M}$ & \pm .02 \\
\hline \multirow[t]{3}{*}{$\begin{array}{l}\text { Consumption } \\
\text { last week }\end{array}$} & $.129 \pm .006$ & $.158 \pm .008$ & $.106 \pm .004$ & $.070 \pm .013$ \\
\hline & \multicolumn{4}{|c|}{$\chi_{6}^{2}=1.91$} \\
\hline & \multicolumn{2}{|c|}{$\mathrm{h}_{\text {Female }}^{2}=55 \pm .02$} & \multicolumn{2}{|c|}{$\mathrm{h}^{2}$ Male $=.36 \pm .02$} \\
\hline
\end{tabular}


Table 11 - Sources of Variance $(\%)$ for log Transformed Measures of Alcohol Consumption

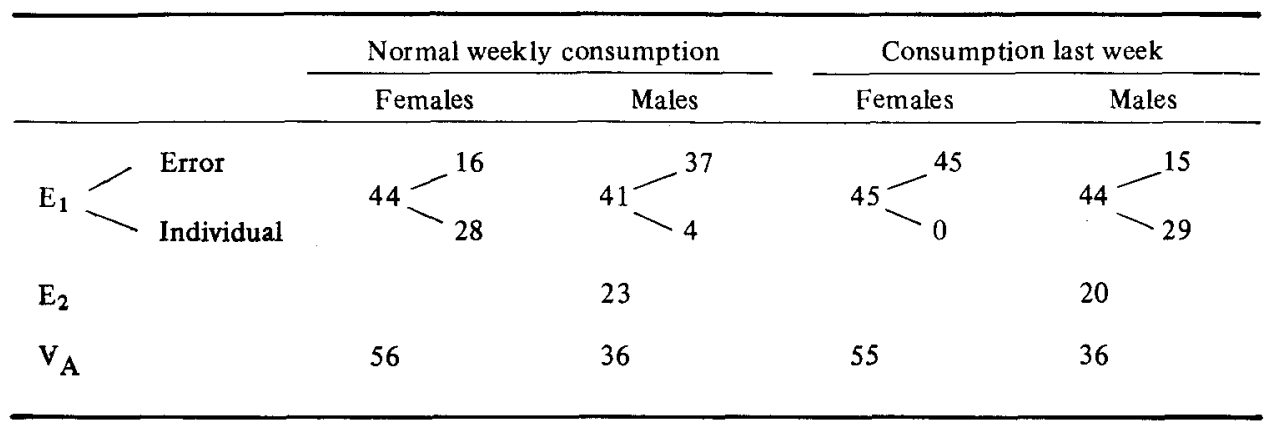

on the age of the individual, we decided to fit models separately for older and younger pairs. We divided the twin pairs into two groups, those 30 and under, and those over 30 .

Just as before, models were first fitted to the mean squares for males and females separately and then to all eight statistics together, models were fitted separately to those 30 and under and those over 30 , and then to all eight statistics combined. The results of fitting these models to normal weekly consumption and consumption last week are shown in Tables 12 and 13.

Although for both measures of consumption in females, the $E_{1} V_{A}$ model gives an excellent fit to the data in both younger and older twins, there is significant heterogeneity of fit over age groups for both normal weekly consumption $\left(\chi_{2}^{2}=31.49 ; \mathrm{P}<0.001\right)$ and consumption last week $\left(\chi_{2}^{2}=6.79, \mathrm{P}<0.05\right)$. While at least some of this heterogeneity is due to an increase in variance with age affecting $E_{1}$ and $V_{A}$ equally for normal weekly consumption, and $\mathrm{V}_{\mathrm{A}}$ for consumption last week, it does suggest that the relative contribution of genetic and environmental factors to total variation is dependent on age. The effect of age is even more striking in males. For both measures of consumption, the $E_{1} V_{A}$ model gives a good fit to the data in younger twins, while for older twins the $E_{1} E_{2}$ model is most appropriate. The effect of $E_{1}$ also increases with age along with this decrease in $V_{A}$ and increase in $E_{2}$. While these results suggest that age-dependent effects are important, it will be necessary to model these effects more precisely in a pedigree analysis of raw scores [9] before we can make any conclusion concerning the change in the relative contribution of genetic and environmental factor's with age.

\section{DISCUSSION}

The preliminary results of this study suggest that the relative contribution of genetic and environmental factors to variation in alcohol consumption is dependent upon age and sex.

In females, when no correction is made for age, approximately $55 \%$ of the variation in consumption is genetic in origin with the remaining variance due to individual environ. mental differences. In contrast, in males only $36 \%$ of the variance is genetic in origin, with approximately $20 \%$ of the total variation due to common environmental influences shared by brothers. That the heritability of consumption is higher in females than males replicates a previous finding [3].

For females, the results for older and younger twins are similar, some of the heterogeneity over age groups being due, no doubt to an increase in variance with age. For 
Tabie 12 - Summary of Fitting Models to $\log$ Transformed Normal Weekly Consumption for Younger and Older Twins

\begin{tabular}{|c|c|c|c|c|c|c|c|}
\hline Data & Model & $\mathrm{E}_{1}$ & $\mathrm{E}_{2}$ & $\mathrm{~V}_{\mathrm{A}}$ & $\mathrm{df}$ & $x^{2}$ & $h^{2}$ \\
\hline \multicolumn{8}{|l|}{ Ficmales } \\
\hline \multirow[t]{3}{*}{ Younger } & $\mathrm{E}_{1} \mathrm{I}_{2}$ & $.106 * * *$ & $.099 * * *$ & & 2 & $35.53^{* * *}$ & \\
\hline & $\mathrm{F}_{1} \mathrm{~V}_{\mathrm{A}}$ & $.085 * * *$ & & $.119 * * *$ & 2 & 0.78 & $.58 \pm .03$ \\
\hline & $E_{1} L_{2} V_{A}$ & $.086 * * *$ & .009 & $.109 * * *$ & 1 & 0.56 & \\
\hline \multirow[t]{3}{*}{ Older } & $E_{1} \mathrm{E}_{2}$ & $.141^{* * *}$ & $.119 * * *$ & & 2 & $30.38 * * *$ & \\
\hline & $\mathrm{E}_{1} \mathrm{~V}_{\mathrm{A}}$ & $.116^{* * *}$ & & $.143 * * *$ & 2 & 0.72 & $.55 \pm .03$ \\
\hline & $\mathrm{l}_{1} \mathrm{l}_{2} \mathrm{~V}_{\mathrm{A}}$ & $.117 * * *$ & .108 & $.131 * * *$ & 1 & 0.53 & \\
\hline \multirow{3}{*}{$\begin{array}{l}\text { Younger } \\
\text { and older }\end{array}$} & $\mathrm{L}_{1} \mathrm{~L}_{2}$ & $.125^{* * *}$ & $.110^{* * * *}$ & & 6 & $92.05^{* * *}$ & \\
\hline & $\mathrm{I}_{1} \mathrm{~V}_{\Lambda}$ & $.101^{* * *}$ & & $.131^{* * *}$ & 6 & $32.99 * * *$ & \\
\hline & $\mathrm{E}_{1} \mathrm{E}_{2} \mathrm{~V}_{\mathrm{A}}$ & $.102 * * *$ & .010 & $.121^{* * *}$ & 5 & $32.58 * * *$ & \\
\hline \multicolumn{8}{|l|}{ Males } \\
\hline \multirow[t]{3}{*}{ Younger } & $\mathrm{H}_{1} \mathrm{E}_{2}$ & $.152 * * *$ & $.196^{* * *}$ & & 2 & $16.39 * * *$ & \\
\hline & $1 v_{1} v_{A}$ & $.116 * * *$ & & $.227 * * *$ & 2 & 3.13 & $.66 \pm .03$ \\
\hline & $E_{1} L_{2} V_{A}$ & $.120 * * *$ & $.072 *$ & $.155^{* * *}$ & 1 & 0.38 & \\
\hline \multirow[t]{3}{*}{ Older } & $\mathrm{E}_{1} \mathrm{E}_{2}$ & $.185^{* * *}$ & $.186^{* * *}$ & & 2 & 0.43 & \\
\hline & $\mathrm{E}_{1} \mathrm{v}_{\mathrm{A}}$ & $.170 * * *$ & & $.198 * * *$ & 2 & $9.29 * *$ & \\
\hline & $\mathrm{E}_{1} \mathrm{E}_{2} \mathrm{~V}_{\mathrm{A}}$ & $.180 * * *$ & $.164 * * *$ & .026 & 1 & 0.15 & \\
\hline \multirow{3}{*}{$\begin{array}{l}\text { Younger } \\
\text { and older }\end{array}$} & $\mathrm{E}_{1} \mathrm{~F}_{2}$ & $.168 * * *$ & $.191^{* * *}$ & & 6 & $18.81^{* *}$ & \\
\hline & $\mathrm{E}_{1} \mathrm{~V}_{\mathrm{A}}$ & $.143^{* * *}$ & & $.211 * * *$ & 6 & $25.41^{* * *}$ & \\
\hline & $\mathrm{L}_{1} \mathrm{~L}_{2} \mathrm{~V}_{\mathrm{A}}$ & $.151^{* * *}$ & $.118^{* * *}$ & $.090^{* *}$ & 5 & $12.44^{*}$ & \\
\hline
\end{tabular}

Table 13 - Summary of Fitting Models to $\log$ Transformed Consumption Last Week for Younger and Older Twins

\begin{tabular}{|c|c|c|c|c|c|c|c|}
\hline Data & Model & $\mathrm{E}_{1}$ & $E_{2}$ & $\mathrm{v}_{\mathrm{A}}$ & $\mathrm{df}$ & $\chi^{2}$ & $\mathrm{~h}^{2}$ \\
\hline \multicolumn{8}{|l|}{ Females } \\
\hline Younger & $\begin{array}{l}F_{1} V_{2} \\
V_{1} V_{A} \\
F_{1} V_{2} V_{A}\end{array}$ & $\begin{array}{l}.128 * * * \\
.108 * * * \\
.109 * * *\end{array}$ & $\begin{array}{l}.093 * * * \\
.012\end{array}$ & $\begin{array}{l}.111^{* * *} \\
.098^{* * *}\end{array}$ & $\begin{array}{l}2 \\
2 \\
1 .\end{array}$ & $\begin{array}{c}18.65 * * * \\
0.66 \\
0.38\end{array}$ & $.51 \pm .03$ \\
\hline Older & $\begin{array}{l}\mathrm{E}_{1} \mathrm{E}_{2} \\
\mathrm{E}_{1} \mathrm{~V}_{\mathrm{A}} \\
\mathrm{E}_{1} \mathrm{E}_{2} \mathrm{~V}_{\mathrm{A}}\end{array}$ & $\begin{array}{l}.132 * * * \\
.105^{* * *} \\
.104 * * *\end{array}$ & $\begin{array}{l}.116^{* * *} \\
-.009\end{array}$ & $\begin{array}{l}.142^{* * *} \\
.151^{* * *}\end{array}$ & $\begin{array}{l}2 \\
2 \\
1\end{array}$ & $\begin{array}{c}45.21 * * * \\
0.72 \\
0.59\end{array}$ & $.58 \pm .02$ \\
\hline $\begin{array}{l}\text { Younget } \\
\text { and older }\end{array}$ & $\begin{array}{l}\mathrm{E}_{1} \mathrm{E}_{2} \\
\mathrm{E}_{1} \mathrm{~V}_{\mathrm{A}} \\
\mathrm{E}_{1} \mathrm{~L}_{2} \mathrm{~V}_{\mathrm{A}}\end{array}$ & $\begin{array}{l}.130 * * * \\
.107 * * * \\
.107 * * *\end{array}$ & $\begin{array}{l}.105^{* * * *} \\
.001\end{array}$ & $\begin{array}{l}.128 * * * \\
.127 * * *\end{array}$ & $\begin{array}{l}6 \\
6 \\
5\end{array}$ & $\begin{array}{l}70.78^{* * *} \\
8.17 \\
8.17\end{array}$ & \\
\hline \multicolumn{8}{|l|}{ Males } \\
\hline Younger & $\begin{array}{l}\mathrm{E}_{1} \mathrm{E}_{2} \\
\mathrm{~L}_{1} \mathrm{~V}_{\mathrm{A}} \\
\mathrm{E}_{1} \mathrm{I}_{2} \mathrm{~V}_{\mathrm{A}}\end{array}$ & $\begin{array}{l}.169 * * * \\
.136 * * * \\
.140^{* * *}\end{array}$ & $\begin{array}{l}.181 * * * \\
.072 *\end{array}$ & $\begin{array}{l}.210^{* * *} \\
.136^{* *}\end{array}$ & $\begin{array}{l}2 \\
2 \\
1\end{array}$ & $\begin{array}{c}10.56^{* *} \\
2.87 \\
0.30\end{array}$ & $.61 \pm .03$ \\
\hline Oider & $\begin{array}{l}E_{1} E_{2} \\
E_{1} V_{A} \\
E_{1} E_{2} V_{A}\end{array}$ & $\begin{array}{l}.195^{* * *} \\
.174^{* * *} \\
.180^{* * *}\end{array}$ & $\begin{array}{l}.171^{* * *} \\
.102^{*}\end{array}$ & $\begin{array}{l}.192^{* * *} \\
.085\end{array}$ & $\begin{array}{l}2 \\
2 \\
1\end{array}$ & $\begin{array}{l}3.13 \\
4.08 \\
0.40\end{array}$ & \\
\hline $\begin{array}{l}\text { Younger } \\
\text { and older }\end{array}$ & $\begin{array}{l}E_{1} E_{2} \\
E_{1} V_{A} \\
E_{1} E_{2} V_{A}\end{array}$ & $\begin{array}{l}.181^{* * *} \\
.155^{* * *} \\
.161^{* * *}\end{array}$ & $\begin{array}{l}.176^{* * *} \\
.088^{* *}\end{array}$ & $\begin{array}{l}.200^{* * *} \\
.108^{* *}\end{array}$ & $\begin{array}{l}6 \\
6 \\
5\end{array}$ & $\begin{array}{c}15.45^{*} \\
12.16 \\
5.35\end{array}$ & \\
\hline
\end{tabular}


males, however, the effect of age is striking. In younger male twins over $60 \%$ of the variance is genetic in origin, with the remaining variance due to environmental influences unique to the individual. In older twins, however, genetic differences do not appear to be important, with approximately $50 \%$ of the total variance due to individual environmental differences and the remaining $50 \%$ due to the effect of common family environment. Obviously, our breakdown of the sample into older and younger twins is rather arbitrary, although in a future paper we will incorporate a pedigree analysis of the raw scores where age effects can be modelled more precisely.

Acknowledgments. The Australian Twin Registry is supported by the National Health and Medical Research Council and the analysis of these data is supported by a grant from the Australian Associated Brewers.

\section{REFERENCES}

1. Australian Bureau of Statistics (1978): Alcohol and tobacco consumption patterns, February 1977. Catalogue No. 4312.0 .

2. Bedford A, Foulds GA, Sheffield BF (1976): A new personal disturbance scale (DSSI/sAD). Br J Soc Clin Psy chol 15:387-394.

3. Cederlöf R, Friberg L, Lundman $T$ (1977): The interactions of smoking, environment and heredity and their implications for disease ae tiology. Acta Med Scand 202/Suppl. 612:1-128.

4. Clark P, Jardine R, Martin NG, Stark AE, Walsh RJ (1980): Sex differences in the inheritance of some anthropometric characters in twins. Acta Genet Med Gemellol 29:171-192.

5. Clark P, Jardine R, Jones P, Martin NG, Walsh RJ (1981): Directional dominance for low IgM and IgA levels. Am J Hum Genet 33:709-721.

6. Clifford CA, Fulker DW, Gurling HMD, Murray RM (1981): Preliminary findings from a twin study of alcohol use. In Gedda L, Parisi P, Nance WE (eds): Twin Research 3: Part C, Epidemiological and Clinical Studies. New York: Alan R. Liss, p 47-52.

7. Conterio F, Chiarelli B (1962): Study of the inheritance of some daily life habits. Heredity 17:347-359.

8. Eaves LJ, Eysenck HJ (1975): The nature of extraversion: A genetical analysis. J Pers Soc Psychol 32:102-112.

9. Eaves LJ, Last K, Young PA, Martin NG (1978): Model-fitting approaches to the analysis of human variation. Heredity 41:249-320.

10. Eysenck HJ, Eysenck SBG 1(1975): Manual of the Eysenck Personality Questionnaire (Junior \& Adult). Holder and Stough ton Educational, Buckhurst Hill, Essex: Chigwell Press Ltd.

11. Fitzgerald JL, Mulford HA (1978): Distribution of alcohol consumption and problem drinking: comparison of sales records and sur vey data. J Stud Alcohol 39:879-893.

12. Jardine R, Martin NG, Henderson AS (1984). Genetic covariation between neuroticism and the symptoms of anxiety and depression. Genet Epidemiol 12:89-107.

13. Jinks JL, Fulker DW (1970): Comparison of the biometrical genetical, MAVA, and classical approaches to the analysis of human behaviour. Psychol Bull 73:311-348.

14. Kaprio J, Koskenvuo M, Sarna S (1981): Cigarette smoking, use of alcohol, and leisure-time physical activity among same-sexed adult male twins. In Gedda L, Parisi P, Nance WE (eds), Twin Research 3: Part C, Epidemiological and Clinical Studies. New York: Alan R. Liss, p $37-46$.

15. Langinvainio H, Kaprio J, Koskenvuo M, Tarkkonen L (1981): Structural analy sis of smoking, alcohol use, personality factors in $\mathrm{MZ}$ and $\mathrm{DZ}$ twin pair relationships. In Gedda L, Parisi P, Nance WE (eds): Twin Research 3: Part C, Epidemiological and Clinical Studies. New York: Alan R. Liss, p 23-35.

16. Martin NG, Eaves LJ, Kearsey MJ, Davies P (1978): The power of the classical twin study. Heredity 40:97-116. 
17. Martin NG, Eysenck HJ (1976): Genetic factors in sexual behaviour. In HJ Eysenck: Sex and Personality, London: Basic Books, p 192-219.

18. Martin NG, Loesch DZ, Jardine R, Berry HS (1982): Evidence for directional non-additivity in the genetics of finger ridge counts. Ann Hum Biol 9:253-263.

19. Partanen J, Bruun K, Markkanen T (1966): Inheritance of Drinking Behavior. A Study of Intelligence, Personality and Use of Alcohol of Adult Twins. Helsinki: Finnish Foundation for Alcohol Studies.

20. Pernanen K (1974): Validity of survey data on alcohol use. In Gibbins RJ, Israel Y, Kalant H, Popham RE, Schmidt W, Smart RG (eds): Research Advances in Alcohol and Drug Problems. New York: Wiley, Vol 1, p 355-374.

21. Perry A (1973): Heredity, personality traits, product attitude, and product consumption - An exploratory study. J Marketing Res 10:376-379.

22. Popham RE, Schmidt W (1981): Words and deeds: The validity of self-report data on alcohol consumption. J Stud Alcohol 42:355-358.

23. Reynolds I, Gallagher H, Bryden D (1977): Heavy drinking and regular drug-taking amongst a sample of Sydney adults. Aust J Alcohol Drug Depend 4:125-127.

24. Smart RG (1968). Alcohol consumption and anxiety in college students. J Gen Psychol 78:3539.

25. Wilson GD, Patterson JR (1968): A new measure of conservatism. Brit J Social Clin Psychol $7: 264-269$.

Correspondence: Dr. N.G. Martin, Department of Human Genetics, B ox 33, MCV Station, Richmond, VA 23298 , USA. 
APPENDIX: Items on Alcohol Use from Questionnaire Sent to Twin Population Surveyed

Have you EVER taken alooholic drinks? If wO go to next page.

\section{At what age did you start drinking alcohol?}

(37)

DURING WEEK DAYS (Monday to Friday)

would you usually drink?

\begin{tabular}{|l|l|l|}
\hline 1 & On two days & \\
\hline 2 & On one day & \\
\hline 3 & Not usually & \\
\hline
\end{tabular}

\begin{tabular}{|l|l|l|l|}
\hline 1 & Each day & \\
\hline 2 & On three or four days & \\
\hline $\begin{array}{l}\text { DURING WEEK DAYS (Monday to Friday) } \\
\text { would you usually drink? }\end{array}$ & On two days & \\
\hline 4 & On one day & \\
\hline 5 & Not usually & \\
\hline
\end{tabular}

\begin{tabular}{|l|l|l|}
\hline 1 & About the same & 27 \\
\hline 2 & Drink LESS now & \\
\hline 3 & Drink MORE now & \\
\hline
\end{tabular}

\begin{tabular}{|l|l|l|l|l|}
\cline { 2 - 5 } & Weekdays & \multicolumn{2}{|c|}{ Weekends } \\
\hline Glasses of wine per day & & & & \\
\hline Glasses of spirits per day & & & & \\
\hline Glasses of sherry per day & & & & \\
\hline $\begin{array}{l}\text { Other (spectfy type and } \\
\text { amount) }\end{array}$ & & & & \\
\hline
\end{tabular}

Please describe your consumption of alcohol in the LAST WEEK. Write in the chart below the number of glasses you had on each day.

\begin{tabular}{|lr|r|r|r|l|l|l|l|}
\hline & & Mon & Tues & Wed & Thur & Fr1 & Sat & Sun \\
\hline Beer & 48 & & & & & & & \\
\hline Wines & 62 & & & & & & & \\
\hline Spir1ts & & & & & & & & \\
\hline Sherry & 90 & & & & & & & \\
\hline Other & & & & & & & \\
\hline
\end{tabular}

(41) During the LAST WEEK, was your conaumption? $\rightarrow$ 